\title{
Rational choice of a minimally invasive method of treatment in uncomplicated nephrolithiasis with kidney calculi from 1.0 to $2.5 \mathrm{~cm}$
}

\author{
A. I. Sagalevich ${ }^{1}$, O. S. Vozianov ${ }^{1}$, R. V. Sergiychuk ${ }^{1}$, B. V. Dzhuran ${ }^{1}$, V. V. Kogut ${ }^{1}$, \\ F. Z. Gaysenyuk ${ }^{1}$, V. V. Ozhohin ${ }^{1}$, F. V. Korytskyi
}

${ }^{1}$ Department of Urology, National Medical Academy of Postgraduate Education named P. L. Shupyk, Kyiv, Ukraine, ${ }^{2}$ Kyiv Regional Hospital, Ukraine

Key words: nephrolithiasis, mini percutaneous nephrolithotripsy, extracorporeal shock wave lithotripsy.

\section{Zaporozhye} medical journal 2018; 20 (1), 58-62 DOI: $10.14739 / 2310-1210$ 2018.1.121993

E-mail: sagalevich260570@ gmail.com
Study purpose - to improve the solitary nephrolithiasis treatment effectiveness by determining the optimal conditions for ESWL or mini PNL application in the treatment of kidney calculi 1.0 to $2.5 \mathrm{~cm}$ in size.

Patients and methods. A comparative analysis of the results of minimally invasive methods application for nephrolithiasis treatment was performed in 210 patients treated with mini PNL (the group I) and 190 patients treated with ESWL (the group II). Patients with calculi more than $1.5 \mathrm{~cm}$ predominated in the group of mini PNL and with calculi less than $1.5 \mathrm{~cm}-$ in the ESWL group. The number of patients with calculi $1.5-2.0 \mathrm{~cm}$ in both groups was the same: $24.3 \%$ and $24.2 \%(P>0.05)$.

Results. It was noted that the calculi destruction effectiveness after 1-4 or more sessions of ESWL took place in 182 patients $(95.8 \%)$. At the same time, an increase in the mean density of calculi above $600 \mathrm{HU}$ caused reduction $(\mathrm{P}<0.001)$ of the primary ESWL session efficiency almost twofold. When performing the $221 \mathrm{mPNL}, 97.1 \%$ of the patients required one surgical treatment. The number of complications (bleeding, attack of pyelonephritis) in the group II was insignificantly higher in contrast to the group I - $26(12.3 \%)$ and $45(14.1 \%)$, respectively $(P<0.05)$. The stone-free status (up to one month) was noted in $62.6 \%$ of patients after the completion of ESWL sessions that increases the risk of nephrolithiasis recurrence from $37.4 \%$. In treatment with $\mathrm{mPNL}$, the stone-free status reached $97.1 \%(\mathrm{P}<0.001)$, and in repeated $\mathrm{mPNL}$ applying in $2.8 \%$ of cases $100 \%$. The mean clinic postoperative treatment periods in the group I were lower in contrast to patients of the group II $3.0 \pm 1.5$ and $12.5 \pm 3.6$, respectively $(P<0.001)$.

Conclusions. This comparative analysis of features and results of uncomplicated nephrolithiasis with $\mathrm{mPNL}$ and ESWL treatment indicates that mPNL is the most preferred method for kidney calculi 1.0 to $2.5 \mathrm{~cm}$ and more in size treatment.
Ключові слова: нефролітіаз, екстракорпоральна уАарно-хвильова мітотрипсія, міні-перкутанна нефролітотрипсія.

Запорізький медичний журнак. - 2018. T. 20, № 1(106). C. 58-62

\section{Раціональний вибір малоінвазивного методу мікування при неускиадненому нефролітіазі з конкрементами нирки від 1,0 до 2,5 cм}

А. І. Сагалевич, О. С. Возіанов, Р. В. Сергійчук, Б. В. Ажуран, В. В. Когут, Ф. З. Гайсенюк,

В. В. Ожогін, А. В. Корицький

Мета роботи - підвищити ефективність лікування солітарного нефролітіазу шляхом визначення оптимальних умов для застосування ЕУХЛ або міні-ПНЛ у лікуванні каменів нирок розмірами 1,0-2,5 см.

Матеріали та методи. Здійснили порівняльний аналіз результатів застосування малоінвазивних методів лікування несролітіазу у 210 пацієнтів, які лікувалися методом міні-ПНЛ (I група), та 190 хворих, які лікувалися за допомогою ЕУХЛ (II група). У групі міні-ПНЛ переважали пацієнти з конкрементами понад 1,5 см, а у групі ЕУХЛ - із конкрементами розмірами менше ніж 1,5 см. Кількість хворих із конкрементами розмірами 1,5-2,0 см в обох групах однакова: відповідно 24,3 \% і 24,2 \% ( $p>0,05)$.

Результати. Відзначено, що ефективність руйнування конкрементів після 1-4 і більше сеансів ЕУХЛ була у 182 пацієнтів (95,8 \%). При цьому збільшення середньої щільності каменів понад 600 од. НU призвело до зниження $(p<0,001)$ ефективності первинного сеансу ЕУХЛ практично вдвічі. При виконанні 221 мПНЛ, 97,1% хворим потрібно було одне хірургічне втручання. Кількість ускладнень (кровотеча, атака пієлонефриту) у II групі хворих була суттєво більшою, ніж у I групі - відповідно 26 (12,3 \%) і 45 (14,1 \%) (р < 0,05). Статус «stone-free» (до одного місяця) після завершення сеансів ЕУХЛ відзначений у 62,6 \% пацієнтів, що збільшує ризик розвитку рецидиву несролітіазу до $37,4 \%$. При лікуванні методом мПНЛ статус «stone-free» досягнутий у 97,1 \% ( $<<0,001)$, а застосована у 2,8 \% випадків повторна мПНЛ - до $100 \%$. Середні стаціонарні післяопераційні терміни лікування в I групі були нижчі на відміну від пацієнтів ІІ групи - 3,0 $\pm 1,5$ і 12,5 $\pm 3,6$ відповідно ( $p<0,001)$.

Висновки. Наведений порівняльний аналіз особливостей і результатів лікування неускладненого нефролітіазу за допомогою мПНЛ та ЕУХЛ свідчить, що мПНЛ - найкращий метод лікування конкрементів нирок розмірами від 1,0 до 2,5 см і більше.

Киючевые слова: нефролитиаз, мини-перкутанная нефролитотрипсия, экстракорпоральная ударно-волновая китотрипсия.

\section{Рациональный выбор малоинвазивного метода лечения} при неосложненном нефролитиазе с конкрементами почки от 1,0 до 2,5 cм

А. И. Сагалевич, А. С. Возианов, Р. В. Сергийчук, Б. В. Ажуран, В. В. Когут, Ф. З. Гайсенюк, В. В. Ожогин, А. В. Корицкий

Цель работы - повысить эффективность лечения солитарного нефролитиаза путем определения оптимальных условий для применения ЭУВЛ или мини-ПНЛ в лечении камней почек размерами 1,0-2,5см. 
Материалы и методы. Проведен сравнительный анализ результатов применения малоинвазивных методов лечения нефролитиаза у 210 пациентов, которые лечились методом мини-ПНЛ (І группа) и 190 больных, леченных с помощью ЭУВЛ (II группа). В группе мини-ПНЛ преобладали пациенты с конкрементами более 1,5cм, а в группе ЭУВЛ - с конкрементами размерами менее 1,5 см. Количество больных с конкрементами размером 1,5-2,0 см в обеих группах одинаково: соответственно $24,3 \%$ и $24,2 \%$ ( $p>0,05)$.

Результаты. Отмечено, что эффрективность разрушения конкрементов после 1-4 и более сеансов ЭУВЛ имела место у 182 пациентов (95,8 \%). При этом увеличение средней плотности камней свыше $600 \mathrm{HU}$ привело к снижению $(p<0,001)$ эфффективности первичного сеанса ЭУВЛ практически вдвое. При выполнении 221 мПНЛ 97,1 \% больным потребовалось одно оперативное вмешательство. Количество осложнений (кровотечение, атака пиелонефрита) во II группе больных было незначительно больше в отличие от I группы - соответственно $26(12,3 \%)$ и 45 $(14,1 \%)(p<0,05)$. Статус «stone-free» (до одного месяца) после завершения сеансов ЭУВЛ отмечен у 62,6 \% пациентов, что увеличивает риск развития рецидивирования нефролитиаза от $37,4 \%$. При лечении методом мПНЛ статус «stone-free» достиг $97,1 \%$ ( $<<0,001)$, а при применении в 2,8 \% случаев повторных мПНЛ - 100 \%. Средние стационарные послеоперационные сроки лечения в I группе были ниже в отличие от пациентов II группы - 3,0 $\pm 1,5$ и 12,5 $\pm 3,6$ соответственно $(p<0,001)$.

Выводы. Приведенный сравнительный анализ особенностей и результатов лечения неосложненного нефролитиаза с помощью мПНЛ и ЭУВЛ свидетельствует о том, что мПНЛ является наиболее предпочтительным методом лечения конкрементов почек размерами от 1,0 до 2,5 см и более.

Over the past $30-40$ years, significant changes have occurred in the treatment of nephrolithiasis, so if in the 70-80s the only active method of nephrolithiasis treatment was an open operation, now such surgeries are very rare (up to $2-3 \%)$, at the very least in leading clinics $[1,3-5]$.

Since the application of extracorporeal shock wave lithotripsy (ESWL) and endourological surgeries are widely used, the treatment of urolithiasis was fundamentally changed. The development of endoscopic technologies resulted in an increase in the number of percutaneous interventions for urolithiasis. Moreover, the technical possibilities of percutaneous nephrolithotripsy (PNL) performing with a tendency to minimize the nephroscopic access size in order to increase the safety of the operation is observed at the method development. The developed methods of mini, ultra-mini and micro-percutaneous nephrolithotripsy (m-PNL, ultramini-PNL, micro-PNL) provide high efficiency of kidney stone disease treatment with minimal risk of complications $[5,7,8]$.

At the same time, the minimal morbidity associated with the new methods application has made it possible to significantly improve the compliance of patients with nephrolithiasis to initiation of therapy in the early stages of disease. And minimally invasive operations can be performed repeatedly in recurrent nephrolithiasis without a significant increase in the risk of renal function impaired or increased technical difficulties that significantly improves the prognosis for these patients [5-7].

PNL is recommended for large calculi (more than 2.0$2.5 \mathrm{~cm}$ ), as well as for the lower calyx calculi $1.0-2.0 \mathrm{~cm}$ in size, if there is a low probability of fragments self-detachment after ESWL, in up-to-date recommendations of the European Association of Urology, 2017. Technological developments and the experience accumulation resulted in an expansion of indications for percutaneous extraction of any density, location and size calculi, as well as the regular displacement of remote disintegration due to the low predictability of the method. That's why, the choice of kidney calculi 1.0 to $2.5 \mathrm{~cm}$ in size treatment option remains contentious issue $[2,3,4,9]$.

\section{Patients and methods}

We have carried out a retrospective and prospective comparative analysis of 2 basic minimally invasive methods of nephrolithiasis treatment results in 210 patients, who were treated with $\mathrm{mPNL}$ (the group I) and 190 patients treated with ESWL (the group II) for the period 2012-2017 in the Clinic of Urology of P. L. Shupyk National Medical Academy of Postgraduate Education (base No. 1 - Kyiv Regional Hospital, base No. 2 - Kyiv City Hospital No. 6).

$\mathrm{mPNL}$ operations were performed for all patients according to the standard procedure with X-ray and ultrasound monitoring, using a mini-nephroscope mini tube from 14 to $21 \mathrm{~cm}$, with an epidural anesthesia. Pneumatic and laser lithotripsy was used as a contact lithotriptor. The ESWL was performed for 190 patients according to the standard procedure with the radiological control and with an intravenous sedation anesthesia.

The purpose of this analysis was to clarify the advantages of this or that method of solitary (single) kidney calculi 1.0 to $2.5 \mathrm{~cm}$ in size treatment, so patients with complicated forms of nephrolithiasis haven't been considered. Acomparison of results of these two methods of treatment was carried out for such parameters as the number of operations per one patient, duration of the procedure, number of complications, degree of calculi removal from kidneys - the stone-free state. Fever and its duration, postoperative bed-day, postoperative complications development, and need for additional interventions were studied in the postoperative period.

The results were assessed regarding the size, number and location of calculi in the renal cavity system. The size of the calculus has meant its the largest diameter. Patients with coral calculi were not included in the study, since our experience indicates that this contingent of patients requires combined treatment, including the main treatment method percutaneous surgery (mPNL) and auxiliary methods ESWL for residual fragments removing and transurethral surgery (ureteroscopy).

Treatment was considered successful, if it was possible to achieve the patient's stone-free state up to $98-100 \%$ or clinically insignificant residual fragments of not more than 2-4 mm in size presence in the kidney without a struvite stone composition and bacteriuria.

Statistical data processing was carried out using the license program package Statistica 6.0 for Windows (StatSoft Inc., USA) using Student's t-test for continuous variables and the chi-square test for categorical variables. Data were considered reliable by the level of statistical significance of $P<0.05$.
Запорожский медицинский журнал. - 2018. T. 20, № 1(106). C. 58-62 
Table 1. Initial localization and size of calculi in patients treated with $\mathrm{mPNL}$ and ESWL

\begin{tabular}{lllll}
\hline Characteristic of kidney calculi & \multicolumn{2}{l}{$m$ PNL $(\mathbf{n}=\mathbf{2 1 0})$} & \multicolumn{2}{c}{ ESWL $(\mathbf{n}=\mathbf{1 9 0})$} \\
\cline { 2 - 5 } & abs. & $\%$ & abs. & $\%$ \\
\hline Localization & 126 & $60.0 \%$ & 93 & $48.9 \%$ \\
Pelvis & 84 & $40.0 \%$ & 97 & $51.1 \%$ \\
Group of calices & 16 & $7.6 \%$ & 18 & $9.5 \%$ \\
- upper & 21 & $10.0 \%$ & 25 & $13.2 \%$ \\
- middle & 47 & $22.4 \%$ & 54 & $28.4 \%$ \\
- lower & & & & \\
\hline Size & 27 & $12.8 \%$ & 112 & $58.9 \%$ \\
$1.0-1.5 \mathrm{~cm}$ & 51 & $24.3 \%$ & 46 & $24.2 \%$ \\
$1.6-2.0 \mathrm{~cm}$ & 132 & $62.9 \%$ & 32 & $16.8 \%$ \\
$2.1-2.5 \mathrm{~cm}$ & & & &
\end{tabular}

Table 2. Comparative analysis of complications in $\mathrm{MPNL}$ and ESWL groups

\begin{tabular}{|c|c|c|}
\hline \multirow[t]{2}{*}{ Index } & \multicolumn{2}{|c|}{ Group of patients } \\
\hline & $\begin{array}{l}\mathrm{mPNL} \\
(\mathrm{n}=210)\end{array}$ & $\begin{array}{l}\text { ESWL } \\
(n=190)\end{array}$ \\
\hline \multicolumn{3}{|l|}{ Mean drop in hemoglobin } \\
\hline $\mathrm{Hb}$ before operation. $\mathrm{g} / \mathrm{l}$ & $140.1 \pm 5.02$ & $141.3 \pm 5.56$ \\
\hline $\mathrm{Hb}$ after operation. $\mathrm{g} / \mathrm{l}$ & $120.9 \pm 5.87$ & $139.9 \pm 5.97$ \\
\hline \multicolumn{3}{|l|}{ Max. temperature rise, $\%$} \\
\hline$>38^{\circ} \mathrm{C}$ & 4.2 & 2.1 \\
\hline $37-38^{\circ} \mathrm{C}$ & 8.1 & 12.1 \\
\hline Calculi fragmentation after first operation, $\%$ & 100.0 & $44.7^{*}$ \\
\hline Implementation of additional minimally invasive interventions, $\%$ & 4.3 & $33.7^{*}$ \\
\hline \multicolumn{3}{|l|}{ Efficiency of fragment elimination for a period of up to one month, \% } \\
\hline $1.0-1.5 \mathrm{~cm}$ & 100 & $75.3^{*}$ \\
\hline $1.6-2.0 \mathrm{~cm}$ & 100 & $62.3^{*}$ \\
\hline $2.1-2.5 \mathrm{~cm}$ & 100 & $45.8^{*}$ \\
\hline Stone-free status for a period of up to one month, $\%$ & 100 & $62.6^{*}$ \\
\hline Average postoperative terms of stay & $3.0 \pm 1.5$ & $12.5 \pm 3.6^{1}$ \\
\hline
\end{tabular}

*: Significant differences from the mPNL group $(P<0.05)$;

1: indicates significant difference from the mPNL group $(P<0.001)$.

\section{Results and discussion}

We studied the initial (preoperative) localization and sizes of kidney calculi in the examined patients of both groups, the data are presented in Table 1.

The Table 1 shows that patients with calculi greater than $1.5 \mathrm{~cm}$ predominate in the $\mathrm{mPNL}$ group, whereas patients with calculi less than $1.5 \mathrm{~cm}$ in sizes predominate in the ESWL group. At the same time, the relative number of patients with calculi $1.6-2.0 \mathrm{~cm}$ in size in both groups is approximately the same: $24.3 \%$ and $24.2 \%$, respectively $(P>0.05)$.

As is known, that effectiveness of ESWL is inversely proportional to the calculus density (we have not carried out ESWL of concrements with a density of more than $1000 \mathrm{HU})$ and its size $[3,5]$. This dependence is also noted in our study, where as a result of the ESWL 190 patients underwent 420 procedures, an average 2.21 procedures per one patient.

Thus, when ESWL was performed in 190 patients with various sizes of calculi, the first session was successful for $85(44.7 \%)$ patients, while 98 (51.5\%) patients required 2 or more sessions, while it was ineffective for 7 (3.7 \%) patients even after $4-5$ sessions of ESWL. So, with calculi 1.0 to $1.5 \mathrm{~cm}$ in sizes the frequency of repeated ESWL was $47.2 \%$; with calculi $1.6-2.0 \mathrm{~cm}$ in size $-62.4 \%$; with calculi
$2.1-2.5 \mathrm{~cm}-81.5 \%$. At the same time, the final result of the calculi destruction effectiveness after 4 or more ESWL sessions took place in 182 patients (95.8\%).

In order to determine dependence of the ESWL procedure effectiveness on kidney calculi, the structural density of solitary kidneys calculi, for which ESWL had been applied, was studied. The average number of ESWL sessions (up to complete fragmentation of the calculus) was $1.33 \pm 0.17$ sessions for $9(4.7 \%)$ patients with calcification density of 200-300 HU, $1.42 \pm 0.05$ sessions for 128 (67.4\%) with calculi density of 301-600 HU, $2.20 \pm 0.14$ sessions for 41 (21.6\%) with density of $601-800 \mathrm{HU}$, and $2.55 \pm 0.30$ for $12(6.3 \pm 1.6 \%)$ with calculi density of $800 \mathrm{HU}$ and more. Thus, it is noted that an increase in the mean calculi density above $600 \mathrm{HU}$ caused reduction $(\mathrm{P}<0.001)$ of the primary ESWL session efficiency almost in twofold.

These data differed among 210 patients treated with $221 \mathrm{mPNL}$, that was 1.05 operations per patient in average, where 204 (97.1\%) patients required only one surgical intervention, while two operations, in order to achieve the stonefree status, were performed only for $6(2.8 \%)$ patients.

Undoubtedly, the main existing minimally and non-invasive methods of nephrolithiasis treatment (PNL and ESWL) are confirmed by high efficiency and minimize the need for open surgical treatment. However, residual calculi and the level of complications remain a problematic issue when choosing a particular minimally invasive method and surgical techniques. [3,4,6].

Based on our observations the number of life-threatening complications (bleeding, attack of pyelonephritis) in the group of patients treated with ESWL was slightly higher in contrast to the group of patients after mPNL $-26(12.3 \%)$ and $45(14.1 \%),(P<0.05)$, respectively, see Table 2.

Despite the fact that a slight drop in hemoglobin in the mPNL group of patients was greater than in the ESWL group, blood transfusion was necessary in no case of mPNL performing.

However, there were a number of differences in the groups with other complications, both during and after the treatment. Thus, patients of the ESWL group significantly more often needed in additional minimally invasive interventions $[5,8]$ which was noted among the groups studied by us, where regardless the additional stages of ESWL sessions, the number of interventions was 64 (33.7 \%) manipulations. This indicator was $4.7 \%$ (10 manipulations) in the MPNL group.

In this case, surgical interventions included hematoma puncture in $1(0.5 \%)$ patient after ESWL. Complications that required drainage for hematomas or urogematomas were not noted in the group of $\mathrm{mPNL}$. Auxiliary mPNL in connection with ineffectiveness of ESWL (large calculi presence in the lower calices group after 3 or more sessions) was performed in $9(4.7 \%)$ patients. An auxiliary ESWL was not performed and repeated $\mathrm{mPNL}$ was performed in $6(2.9 \%)$ cases in the group of patients with mPNL. In contrast, the number of repeated sessions reached 230 (an average of 2.21 per patient) in the group of patients with ESWL.

Ureteroscopy was used in $2(0.95 \pm 1.0 \%)$ cases after mPNLs and in 9 (4.7\%) after ESWL with the purpose of fragments separation of the stone pathway, while ESWL of stone pathway was applied directly in the group of patients after ESWL in 23 (12.1\%) cases. Preliminary (preventive) 
stent application was performed in 18 (9.5\%) patients of the ESWL group. Patients treated with a preliminary drainage in connection with obstructive pyelonephritis were not studied by us. Consequently, the preliminary (preventive) drainage aids were not performed for the planned patients treated with $\mathrm{mPNL}$.

In the postoperative period for calculi fragments obstruction removing, the ureteral stent was applied for 4 $(2.1 \%)$ patients of the ESWL group and for $1(0.47 \%)$ of the mPNL group $(P=0.34)$.

As noted above, the frequency of successful calculi destruction also had differences (even after several interventions) and was recorded at $100 \%$ level in the $\mathrm{mPNL}$ group and $94.2 \%$ in the ESWL group $(P<0.05)$.

In this case, it is necessary to take into account that the methods effectiveness is determined not only by the calculus destruction, but also by the elimination of its fragments. In particular, removal of fragments at mPNL occurs directly during its performance, and only fragmentation of the calculus occurs in ESWL performance, and fragments excretion occurs naturally along the urinary tract $[5,9]$.

It is known that with the increase in the size of kidney solitary calculus, the effectiveness of ESWL is significantly reduced as well $[4,6]$. So we noted that the stone-free status (for up to one month) took place only in 119 patients that was $62.6 \%$, and the remaining patients required further observation or additional auxiliary procedures, and thus it increases the risk of nephrolithiasis recurrence from $37.4 \%$. So, with kidney calculi size of $1.0-1.5 \mathrm{~cm}$ the effectiveness of fragments elimination (for up to one month) after ESWL was $75.3 \%$; with calculi size of $1.6-2.0 \mathrm{~cm}-62.3 \%$; with the size of $2.0-2.5 \mathrm{~cm}-45.8 \%$.

According to some authors' opinion, this feature is fundamentally opposite to the results of mPNL [2], even without combined treatment the effect of complete renal cavity system cleansing from the calculus fragments (stonefree status) is the highest. These data are also supported by our observations, where this parameter when $\mathrm{MPNL}$ using reached $97.1 \%(P<0.001)$, and when repeated $\mathrm{mPNL}$ was applied in $2.8 \%$ of cases $-100 \%$.

The next important comparative feature of these methods of treatment was the average stationary postoperative treatment time which was significantly lower in the group of patients with $\mathrm{mPNL}$ in contrast to patients treated with ESWL $-3.0 \pm 1.5$ and $12.5 \pm 3.6$, respectively, $(P<0.001)$.

It should be noted that in the first group of patients the mean bed-day, as a rule, was standard, nephrostomy drainage was removed for the next day, and the use of non-drainage and completely non-drainage mPNL in 26 (12.3) cases permitted to reduce the mean bed-day to $3.0 \pm 1.5$ days, that's why this situation was significantly different in the second group of patients treated with ESWL. Thus, with calculi $1.0-1.5 \mathrm{~cm}$ in size the length of the patient's stay on the bed after ESWL was 8.9 days; with calculi 1.6-2.0 cm in size - 15.5; with calculi size of more than $2.1-2.5 \mathrm{~cm}-17.1$ days.

\section{Conclusions}

1. The presented comparative analysis shows that ESWL and $\mathrm{mPNL}$ demonstrate high efficiency in the treatment of solitary nephrolithiasis with a calculus 1.0 to $2.5 \mathrm{~cm}$ in size. At the same time, following this analysis result, it can be seen that each of the procedures has its advantages and disadvantages. Thus, the level of effectiveness is higher, when using $\mathrm{mPNL}$, and the profile of potential safety is higher in ESWL, as it is less invasive.

2. $\mathrm{mPNL}$ is the most successful and safe procedure in the treatment of kidney calculi of 1.0 to $2.5 \mathrm{~cm}$ in comparison with ESWL. In turn, ESWL has higher risks of postoperative complications in the form of calculus fragments migration and requires for both preventive and post-operative drainage of the urinary tract. However, these complications are entirely related to the technical features of the method. When using ESWL in nephrolithiasis treatment the determinants of method efficiency and safety, as well as the post-operative rehabilitation period, are the calculus size and density.

However, considering these factors, the use of ESWL in the treatment of kidney calculi 1.0 to $2.5 \mathrm{~cm}$ in size should not be completely rejected, and when choosing a minimally invasive method for nephrolithiasis treatment, a balanced approach to the choice of treatment option is necessary in each specific case which requires further study.

\section{References}

[1] Chang, W. L., \& Murali, S. (2011). Day care percutaneous renal surgery - is this viable? Med.J. Malaysia, 57(1), 108-110.

[2] Ganpule, A. P., Bhattu, A. S., \& Desai, M. (2015). PCNL in the twenty-first century: role of Microperc, Miniperc, and Ultraminiperc. World J. Urol., 33, 235-240. doi: 10.1007/s00345-014-1415-1.

[3] Türk, C., Knoll, T., Petrik, A., Sarica, K., Skolarikos, A., Straub, M., \& Seitz, C. (2017). Guidelines on Urolithiasis. European Association of Urology. Retrieved from http://uroweb.org/wp-content/upload/22-Urilithiasis.

[4] De la Rosette, J., Assimos, D., Desai, M., Gutierrez, J., Lingeman, J., Scarpa, R., \& Tefekli, A. (2011). The clinical research office of the endourological society percutaneous nephrolithotomy Global study: indications, complications, and outcomes in 5803 patients. J. Endourol., 25(1), 11-17. doi: 10.1089/end.2010.0424.

[5] Kumar, A., Kumar, N., Vasudeva, P., Kumar, R., Jha, S. K., \& Singh, H. (2015). A Single Center Experience Comparing Miniperc and Shockwave Lithotripsy for Treatment of Radiopaque 1-2cm Lower Caliceal Renal Calculi in Children: A Prospective Randomized Study. Journal of Endourology, 29(7), 805-809. doi: 10.1089/ end.2015.0020.

[6] Michel, M. S., Trojan, L., \& Rassweiler, J. J. (2007). Complications in percutaneous nephrolithotomy. Eur. Urol., 51(4), 899-906. doi: 10.1016/j.eururo.2006.10.020.

[7] Mishra, S., Sharma, R., Garg, C. Kurien, A., Sabnis, R., \& Desai, M. (2011). Prospective comparative study of miniperc and standard PNL for treatment of 1 to $2 \mathrm{~cm}$ size renal stone. BJU Int., 108(6), 896-900. doi: 10.1111/j.1464-410X.2010.09936.x.

[8] Ghani, K., Andonian, S., Bultitude, M., Desai, M., Giusti, G., Okhu nov, Z., et al. (2016). Percutaneous Nephrolithotomy: Update, Trends, and Future Directions. Eur Urol., 70(2), 382-396. doi: 10.1016/j. eururo.2016.01.047.

[9] Abdelhafez, M. F., Amend, B., Bedke, J., Kruck, S., Nagele, U., Stenzl, A., \& Schilling, D. (2013) Minimally invasive percutaneous nephrolithotomy: a comparative study of the management of small and large renal stones. Urology, 81(2), 241-245. doi: 10.1016/j. urology.2012.09.030

\section{Information about authors:}

Sagalevich A. I., MD, PhD, DSc, Associate Professor, Department of Urology, National Medical Academy of Postgraduate Education named after P. L. Shupyk, Kyiv, Ukraine.

Vozianov 0. S., MD, Assistant, Department of Urology, National Medical Academy of Postgraduate Education named after P. L. Shupyk, Kyiv, Ukraine.

Sergiychuk R. V., MD, Postgraduate Student, Department of Urology, National Medical Academy of Postgraduate Education named after P. L. Shupyk, Kyiv, Ukraine. 
Dzhuran B. V., MD, PhD, Associate Professor, Department of Urology, National Medical Academy of Postgraduate Education named after P. L. Shupyk, Kyiv, Ukraine.

Kogut V. V., MD, PhD, Associate Professor, Department of Urology, National Medical Academy of Postgraduate Education named after P. L. Shupyk, Kyiv, Ukraine.

Gaysenyuk F. Z., MD, PhD, DSc, Associate Professor, Department of Urology, National Medical Academy of Postgraduate Education named after P. L. Shupyk, Kyiv, Ukraine.

Ozhohin V. V., MD, Post-Graduate student, Department of Urology, National Medical Academy of Postgraduate Education named after P. L. Shupyk, Kyiv, Ukraine.

Korytskyi A. V., MD, Head of the Department of Urology, Kyiv Regional Hospital, Ukraine.

\section{Відомості про авторів:}

Сагалевич А. І., А-р меА. наук, Аоцент каф. урології, Національна медична академія післядипломної освіти імені П. ^. Шупика, м. Київ, Україна.

Возіанов О. С., асистент каф. урології, Аоцент, Національна медична академія післядипломної освіти імені П. ^. Шупика, м. Київ, Україна.

Сергійчук Р. В., аспірант каф. урології, Національна медична академія післядипломної освіти імені П. А. Шупика, м. Київ, Україна.

Ажуран Б. В., канА. меА. наук, Аоцент каф. урології, Національна медична академія післядипломної освіти імені П. ^. Шупика, м. Київ, Україна.

Когут В. В., канА. меА. наук, Аоцент каф. урології, Національна медична академія післядипломної освіти імені П. ^. Шупика, м. Київ, Україна.

Гайсенюк Ф. З., А-р меА. наук, Аоцент каф. урології, Національна медична академія післядипломної освіти імені П. ^. Шупика, м. Київ, Україна.

Ожогін В. В., аспірант каф. урології, Національна медична академія післяАипломної освіти імені П. ^. Шупика, Київ, Україна.

Корицький А. В., зав. віААілення урології, Київська обласна мікарня, Україна.

\section{Сведения об авторах:}

Сагалевич А. И., А-р меА. наук, Аоцент каф. урологии, Национальная медицинская академия послеАипломного образования имени П. А. Шупика, г. Киев, Украина. Возианов А. С., ассистент каф. урологии, Национальная медицинская академия последиппомного образования имени П. А. Шупика, г. Киев, Украина.

Сергийчук Р. В., аспирант каф. урологии, Национальная медицинская академия послеАипломного образования имени П. А. Шупика, г. Киев, Украина.

Ажуран Б. В., канА. меА. наук, Аоцент каф. урологии, Национальная медицинская академия последипломного образования имени П. А. Шупика, г. Киев, Украина. Когут В. В., канА. меА. наук, Аоцент каф. урологии, Национальная медицинская академия последипломного образования имени П. А. Шупика, г. Киев, Украина. Гайсенюк Ф. З., А-р меА. наук, Аоцент каф. урологии, Национальная медицинская академия последипломного образования имени П. А. Шупика, г. Киев, Украина. Ожогин В. В., аспирант каф. урологии, Национальная медицинская академия последипломного образования имени П. ^. Шупика, г. Киев, Украина.

Корицкий А. В., зав. отАелением урологии, Киевская областная больница, Украина.

Conflicts of interest: authors have no conflict of interest to declare. Конфмікт інтересів: віАсутній. 